\section{Список литературы:}

1. Васильев И.Б., Кузьмина О.В., Семенова А.П. Периодизация памятников срубной культуры лесостепного Поволжья // Срубная культурно-историческая общность. Куйбышев: Изд-во КГПИ, 1985. С. 64.

2. Кузнецов П.Ф. Время культур позднего бронзового века Поволжья (анализ радиоуглеродных датировок) // Труды IV (XX) Всероссийского археологического съезда в Казани. Том I. Казань: Изд-во «Отечество», 2014. С. 582-584.

3. Пастухова О.С. Градация детских погребений срубной культуры (по материалам курганного могильника Спиридоновка II) // Известия Самарского научного центра Российской академии наук. 2013. T. 15, № 1-1. С. 200-204.

4. Мочалов О.Д. К вопросу о сосудах со знаками срубной культуры Южного Средневолжья // Вопросы археологии Поволжья: сборник статей. Выпуск 3. Самара: Изд-во СНЦ РАН, 2003. С. 306-315.

5. Кузнецов П.Ф., Мочалов О.Д., Пастухова О.С., Хохлов А.А., Жуков Р.А. Работы на курганном могильнике Каменный Овраг II в Кошкинском районе Самарской области // Археологические открытия. 2016. T. 2014. C. 294-295.

6. Жуков Р.В. Сравнительный анализ покровской и срубной погребальных традиций позднего бронзо- вого века (по материалам курганов Самарского Поволжья) // XLIX Урало-Поволжская археологическая экспедиция студентов и молодых ученых: сборник статей. Выпуск 49. Киров: Изд-во Вятского государственного университета, 2017. С. 76-79.

7. Багаутдинов Р.С., Васильева И.Н. Курганные группы Золотая Нива I и II // Вопросы археологии Урала и Поволжья. Выпуск 2. Самара: Изд-во Самарского университета, 2004. С. 181-211.

8. Мерперт Н.Я. Из древнейшей истории Среднего Поволжья // Материалы и исследования по археологии СССР. 1958. № 61. С. 45-156.

9. Кузьмина О.В. ІІІ Подстепкинский могильник // Вопросы археологии Поволжья. Вып. 5. Самара: Изд-во СамНЦ РАН, 2015. С. 226-335.

10. Агапов С.А. Деревянные погребальные сооружения срубной культуры на территории Куйбышевской области // Проблемы археологии Поволжья и Приуралья. Куйбышев: Изд-во КГПИ, 1976. С. 69-70.

11. Ван Геннеп А. Обряды перехода: Системат. изучение обрядов. М.: Вост. лит. РАН, 1999. 198 с.

12. Кузнецов П.Ф. Особенности курганных обрядов населения самарской долины в первой половине бронзового века // Материальная культура населения бассейна реки Самары в бронзовом веке / отв. ред. Ю.И. Колев. Самара: СамГПУ. 2003. С. 43-51.

\title{
POKROVSKY AND SRUBNA CULTURE TRADITIONS OF THE LATE BRONZE AGE IN THE SAMARA VOLGA (IDEOLOGICAL POSITIONS)
}

(C) 2018

Zhukov Roman Vladimirovich, master student of Domestic History and Archeology Department Samara State University of Social Sciences and Education (Samara, Russian Federation)

Abstract. In archeology, there are several approaches to assessing the monuments of the Pokrovsky and the logs of the final stage of the middle - the beginning of the Late Bronze Age, in the Middle Volga Region. The paper presents the results of these studies in archaeology on this topic: Pokrovsky and srubna culture funerary traditions of the late Bronze Age of the Samara Region (world-view positions). As the title suggests the paper is devoted to the problem of differences and ideological justification of funerary traditions of the pokrovsky and srubna culture of the Samara Region. The main objective of the paper is to provide theoretical understanding of the concept of chronology and description of the funerary traditions of cultures. The work consists of an introductory part (historiography), the main part (description of the burial of the Pokrovskaya and srubna culture) and conclusions (ideological substantiation of their funeral traditions). It also presents prospects for further research in this area. At the end of the paper the author analyzes burials of both cultures and the ideological justification of the funerary traditions. The paper has practical significance.

Keywords: funeral rites; outlook; chariot tradition; inside grave facilities; elite group; status of deceased; Cenotaph; lifting material; point graphs; burial chambers; radiocarbon dating; afterlife; transition; conception.

\section{КУРГАН 5 ГРУППЫ «ВОДОВОД» НА ЛЕВОБЕРЕЖЬЕ НИЖНЕГО ДНЕСТРА И СКИФСКИЕ КЕНОТАФЫ СЕВЕРО-ЗАПАДНОГО ПРИЧЕРНОМОРЬЯ}

Синика Виталий Степанович, кандидат исторических наук, доцент, ведущий научный сотрудник научно-исследовательской лаборатории археологии; старший научный сотрудник лаборатории историографии и полевых методов в археологии

Приднестровский государственный университет им. Т.Г. Шевченко (2. Тирасполь, Республика Молдова); Нижневартовский государственный университет

(2. Нижневартовск, Ханты-Мансийский автономный округ - Югра, Российская Федераиия)

Тельнов Николай Петрович, кандидат исторических наук, доцент, заведующий отделом античной и средневековой археологии

Институт культурного наследия Академии наук Республики Молдова (2. Кишинёв, Республика Молдова)

Аннотаиия. В статье публикуются и анализируются материалы, полученные при исследовании скифского кургана 5 группы «Водовод» у с. Глиное на левобережье Нижнего Днестра. Насыпь была возведена на рубе- 
же IV-III вв. до н.э. и содержала восемь скифских погребальных сооружений, три из которых были кенотафами. Подобных символических захоронений в Северо-Западном Причерноморье известно всего 14. Помимо публикуемых в настоящей работе, это комплексы Балабаны 6/1, Семёновка 20, Кочковатое 48/4, Воловарската Могила 1 и 2, Глиное 40/1, Глиное/Водовод 6/3, 6/4, 8/1 и 8/4, Глиное/Сад 7/3. Они были сооружены во второй половине IV-II в. до н.э. Значительное число детских кенотафов (8), позволяет считать, что все они были совершены оседлыми скифами. Использование некоторых комплексов (4 случая - Балабаны 6/1, Семёновка 20, Воловарската Могила 1 и 2) в качестве кенотафов может быть оспорено. В то же время существование настоящих кенотафов (подкурганных комплексов, с погребальным сооружением или без него), предназначавшихся для символических захоронений людей (10 случаев), тела которых по каким-либо причинам не могли быть преданы земле, сомнений не вызывает.

Ключевые слова: скифы; рубеж IV-III вв. до н.э.; левобережье Нижнего Днестра; степь; погребальный обряд; курган; захоронение; яма; катакомба; кенотаф; материальная культура; лепной горшок; ожерелье из бусин; амулеты-подвески; пряслица; серьги; зеркало; перстень; игла; шило; нож; абразив; оседлость; левобережье Нижнего Дуная; Дунай-Днестровское междуречье.

В последние два десятилетия наиболее масштабные исследования скифских погребальных памятников в Северо-Западном Причерноморье проводятся на левобережье Нижнего Днестра. В 1995-2012 гг. были проведены раскопки могильника III-II вв. до н.э. у с. Глиное Слободзейского района. В 2017 г. на этом памятнике в спасательных целях был исследован еще один курган. Всего на данный момент было изучено 114 скифских насыпей, содержавших 183 скифских погребения. На протяжении 2015-2017 гг. скифские курганы и скифские захоронения второй половины IV - первой трети III в. до н.э. были исследованы при раскопках курганных групп «Сад» и «Водовод», располагающихся в непосредственной близости (в 1,8 км к северу) от скифского могильника III-II вв. до н.э. Всего в группах «Сад» и «Водовод» были выявлены 55 скифских захоронений: 48 в скифских курганах и 7 - в курганах эпохи бронзы. И если могильник III-II вв. до н.э. является важнейшим памятником, свидетельствующим о существовании скифской культуры в это время в СевероЗападном Причерноморье [1; 2], то скифские комплексы курганных групп «Сад» и «Водовод» демонстрируют трансформацию классической скифской культуры в позднескифскую [3-9]. В то же время последние содержат информацию, которая позволяет рассматривать и другие вопросы, касающиеся истории скифского населения региона. Одним из них является практика сооружения кенотафов в курганах.

В настоящей работе впервые публикуются и анализируются материалы, полученные при исследовании скифского кургана 5 группы «Водовод», где были выявлены три кенотафа в ямах. Ниже приводится описание этого кургана, исследованных в нем скифских погребений, а также сопровождающего инвентаря. [Чертежи плана кургана и его профилей, планов погребений и их разрезов выполнены канд. ист. наук С.Н. Разумовым, рисунки инвентаря - канд. ист. наук С.Д. Лысенко, за что выражаем им благодарность].

Курган 5 копался параллельными траншеями с использованием техники. Были разбиты три бровки по линии север - юг. Ширина всех бровок по 0,6 м. Длина Центральной бровки 28 м, длина Восточной и Западной бровок по 24 м. Расстояние между бровками 5,5 м (рис. 1). ний.

В кургане выявлено восемь скифских захороне-

Погребение 1 (скифское, впускное, кенотаф) обнаружено во II Западной траншее, в 12,5 м на север и в 1,5 м на запад от центра Западной бровки.
Яма прямоугольной формы размерами $1,60 \times$ $\times 0,47$ м и глубиной $-1,32$ м от $\mathrm{R}_{0}$ была ориентирована по линии северо-запад - юго-восток. Стенки ямы расширялись ко дну. Кости человека, инвентарь, тлен от подстилки не обнаружены (рис. 2: 1, 2).

Погребение 2 (скифское, впускное, кенотаф) обнаружено во II Западной траншее, в 0,5 м на север и в 2 м на запад от центра Западной бровки.

Яма прямоугольной формы размерами $1,65 \times$ $\times 0,55$ м и глубиной $-1,41$ м от $\mathrm{R}_{0}$ была ориентирована по линии северо-запад - юго-восток. Стенки ямы расширялись ко дну. Кости человека, инвентарь, тлен от подстилки не обнаружены (рис. 2: 3, 4).

Погребение 3 (скифское, впускное) обнаружено в I Западной траншее, в 7 м на север и в 1,5 м на запад от $\mathrm{R}_{0}$. Совершено в яме.

Яма подпрямоугольной формы размерами $1,45 \times$ $\times 0,65$ м и глубиной $-1,46$ м от $\mathrm{R}_{0}$ была ориентирована по линии север-северо-восток - юг-юго-запад. Стенки ямы расширялись ко дну.

На дне ямы лежал костяк ребенка 4 лет [10, р. 5] в вытянутом положении на спине, головой на юг-югозапад. Руки вытянуты вдоль тела, ноги прямые. За черепом, в южном углу ямы, стоял лепной сосуд (1). Под нижней челюстью ребенка зафиксировано ожерелье (2) (рис. 2: 5, 6).

\section{Описание находок}

1. Горшок лепной округлобокий с выраженным Sвидным профилем. Венчик воронковидно отогнут, с закругленным краем. Максимальное расширение корпуса приходится на нижнюю половину сосуда. Дно плоское, с выраженной в разной степени закраиной. По шейке сосуд орнаментирован поясом, состоящим из 33 круглых ямок. Высота горшка 126130 мм. Высота венчика 24-28 мм. Высота нижней части 50-55 мм. Диаметр венчика $111 \times 114$ мм. Диаметр шейки $94 \times 97$ мм. Максимальный диаметр тулова $130 \times 132$ мм. Диаметр дна $86 \times 88$ мм. Толщина венчика 6-7 мм. Толщина стенок 7-8 мм. Толщина дна 13 мм. Диаметр ямок 4-6 мм; глубина - 2-3,5 мм (рис. 2: 7). Тесто с примесью шамота. Цвет пятнами желтовато-серый, серый, тёмно-серый. На обеих поверхностях местами сохранился черный нагар.

2. Ожерелье состояло из трех стеклянных бусин и подвески из клыка животного:

- бусина цилиндрическая, глазчатая. Изготовлена из синего стекла; «глазки» белого цвета с синими «зрачками». Всего насчитывается 42 «глазка», расположенных в четыре ряда: первый ряд - 10 «глаз- 
ков», второй -10 , третий - 11, четвертый - 11. Высота бусины 18-19 мм. Диаметр по центру $22 \times 23$ мм; диаметры оснований 17 мм и 17,5 × 18 мм. Диаметр отверстия 10 мм. Диаметр «глазков» 4,5-6,5 мм; диаметр «зрачков» 2-3 мм (рис. 2: 8);

- бусина-пронизь удлиненно-цилиндрическая. Изготовлена из коричневого стекла с белыми разводами. Длина бусины 27 мм. Диаметр по центру 7,5 × $\times 8,1$ мм; диаметры оснований 6,6 мм и 5,5 ×6 мм. Диаметр отверстия 3-4 мм (рис. 2: 9);
- бусина уплощенно-сферическая, асимметричная. Изготовлена из синего стекла. По максимальному диаметру проходит желтая нить. Поверхность покрыта желтоватой патиной. Высота бусины 11,2 мм. Диаметр по центру 13 мм; диаметры оснований 10 мм и 8 мм. Диаметр отверстия 5-5,5 мм (рис. 2: 10);

- подвеска-амулет из клыка собаки (?). Ниже эмали зуба просверлено круглое отверстие. Длина подвески 41,5 мм. Размеры сечения $7 \times$ 7,2 мм. Диаметр отверстия 2,6 мм (рис. 2: 11).

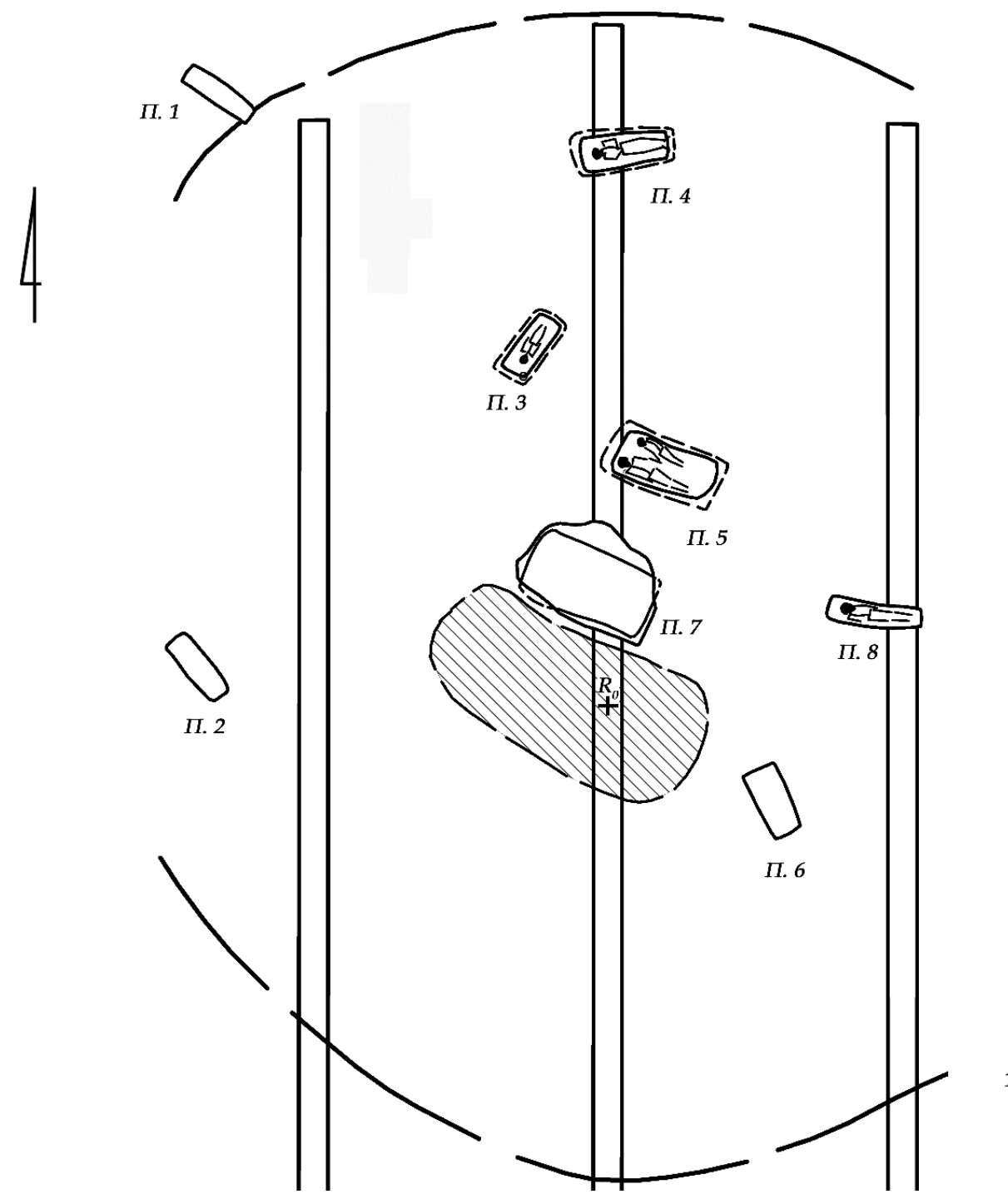

$R_{0} \quad$ Западный профиль Центральной бровки

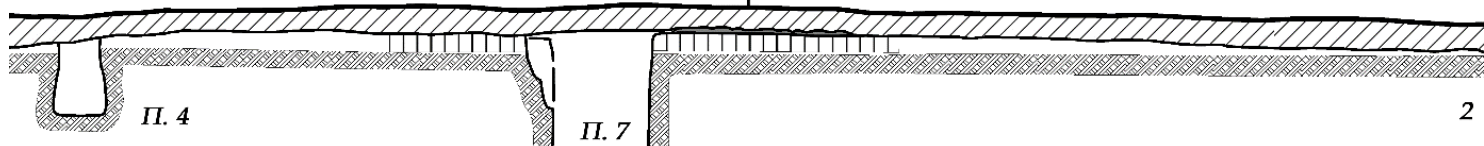

Восточный профиль Центральной бровки

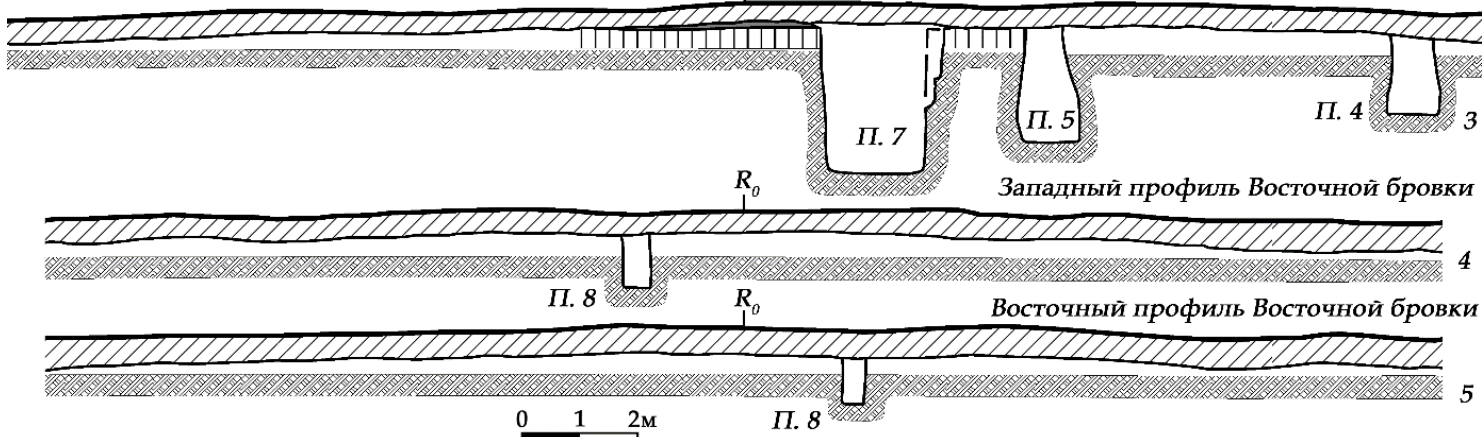

Рисунок 1 - План (1) и профили (2-5) кургана 5 группы «Водовод» на левобережье Нижнего Днестра 

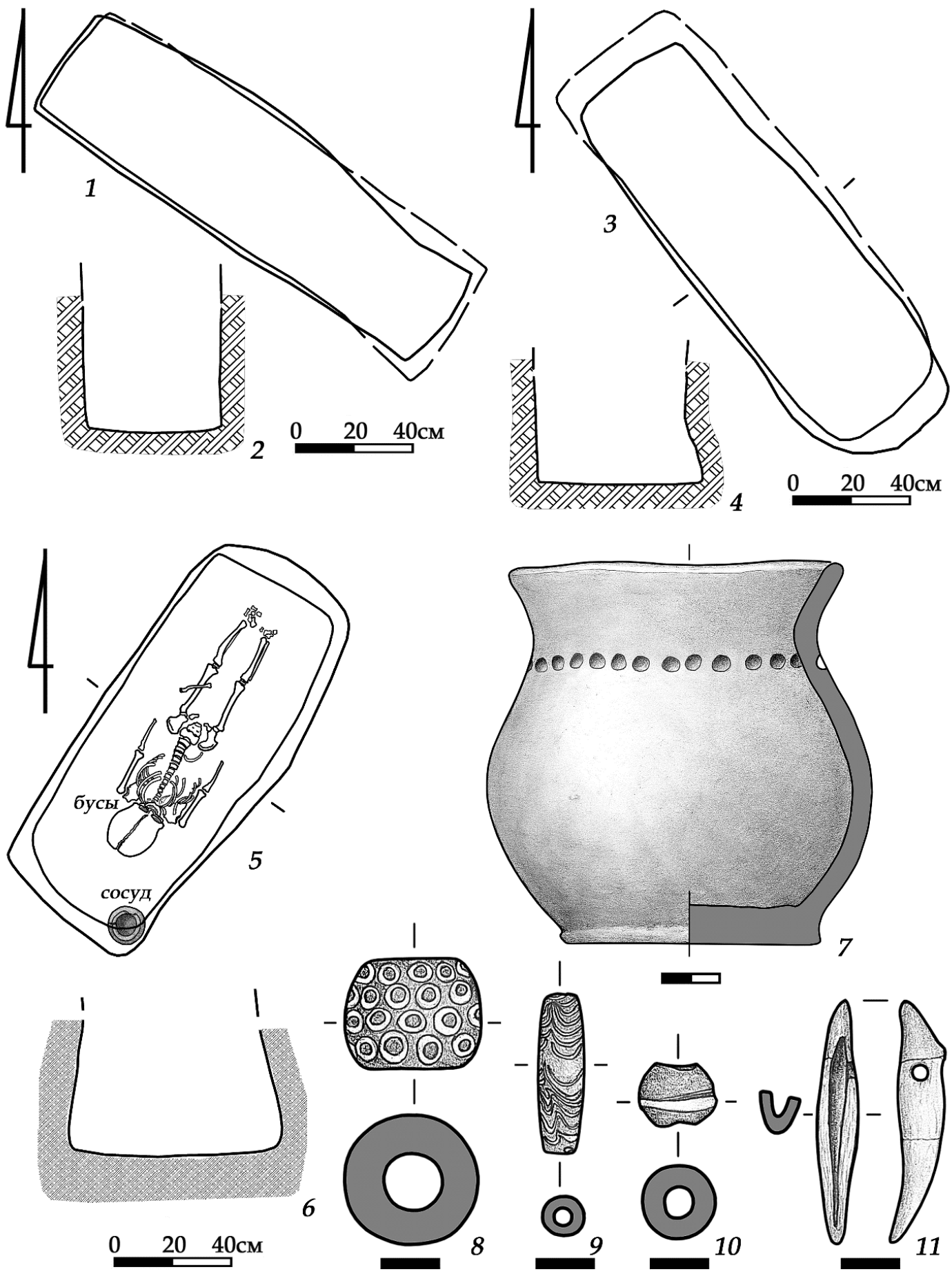

Рисунок 2 - План и профили погребений 1 (1, 2), 2 (3, 4), 3 (5, 6) а также инвентарь из захоронения 3 (7-11) кургана 5 группы «Водовод»

Погребение 4 (скифское, впускное) обнаружено под Центральной бровкой, в 11 м к северу от $\mathrm{R}_{0}$. Coвершено в яме.

Яма прямоугольной формы размерами по дну $2,10 \times 0,70$ м и глубиной $-1,87$ м от $\mathrm{R}_{0}$ была ориентирована по линии запад-юго-запад - восток-северовосток. Стенки ямы расширялись ко дну.

На дне ямы лежал костяк человека возрастом 1520 лет [10, p. 6] в вытянутом положении на спине, головой на запад. Череп завалился на правый висок, руки вытянуты вдоль тела, ноги прямые. Под костяком отмечен светло-серый органический тлен от подстилки (циновка?) размерами 1,55 × 0,5 м.

За черепом, в северо-западном углу ямы, лежали кости животных от жертвенной пищи, среди которых был найден железный нож с роговой рукоятью (1) (рис. 3: 1,2).

\section{Описание находки}

1. Нож железный с горбатой спинкой и с роговыми накладками на рукоять. Роговые пластины прикреплены к черенку с двух сторон четырьмя заклепками. Нижняя часть ручки укреплена железным кольцом. Лезвие подтреугольное в сечении, с закругленной спинкой. Острие обломано. Сохранившаяся длина ножа 199 мм. Длина сохранившегося лезвия 79 мм. Длина рукояти 109 мм. Ширина лезвия до 19 мм, толщина - до 4 мм. Размеры кольца $20 \times 14,5$ мм, ширина - 9 мм. Ширина роговых пластин-накладок (снизу вверх) 14-12,5-18,3 мм; толщина - 2,54,5 мм. Совокупная толщина рукояти до 10 мм. Длина заклепок до 14 мм; диаметр стержня - до 3 мм, диаметр шляпок - до 5 мм (рис. 3: 3). 


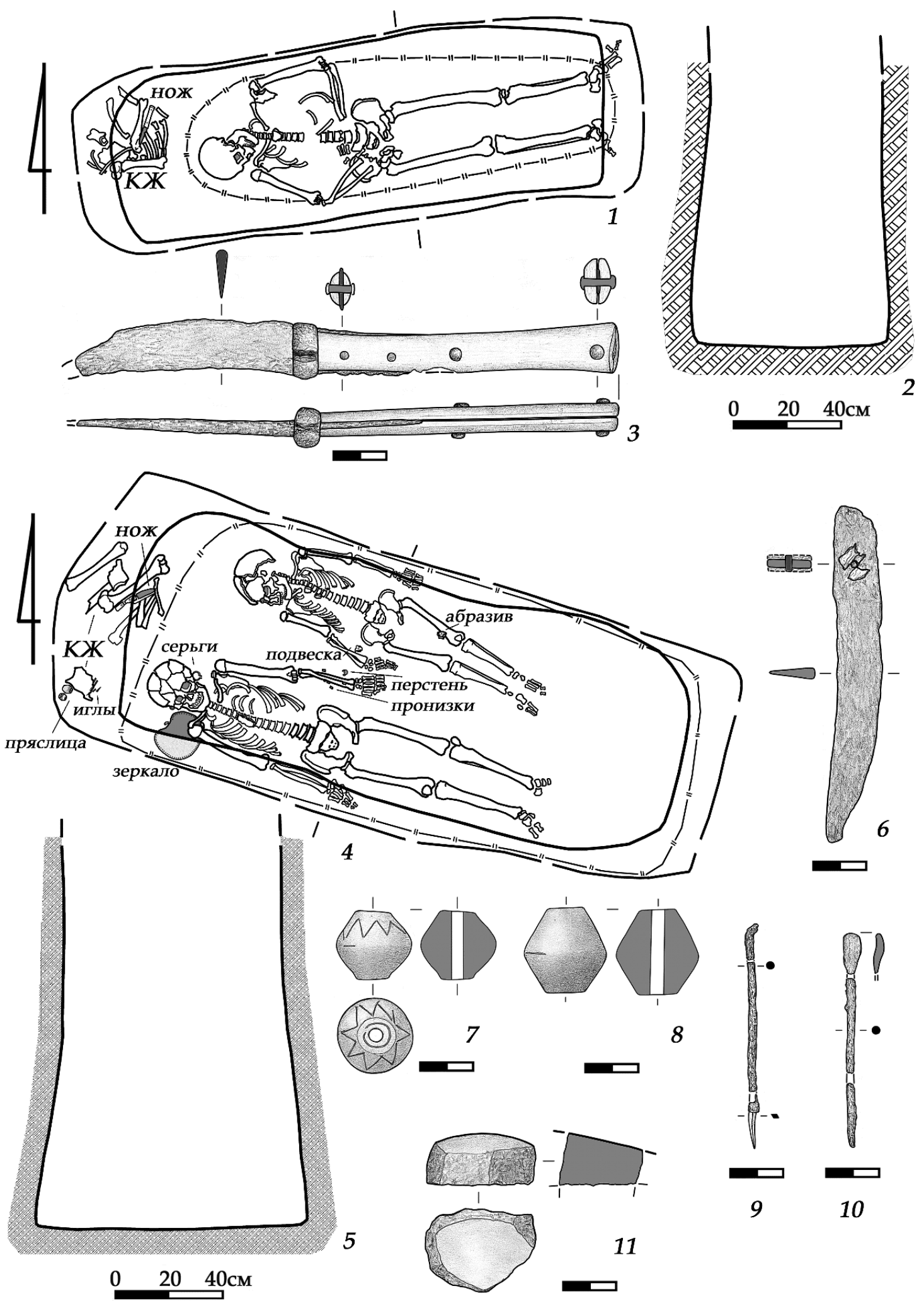

Рисунок 3 - План и профиль погребения $4(1,2)$ и нож из него (3); план и профиль захоронения $5(4,5)$ и находки из него $(6-11)$

Погребение 5 (скифское, впускное) обнаружено в 5 м к северу от $\mathrm{R}_{0}$, под Центральной бровкой и в I Восточной траншее. Совершено в яме.

Яма прямоугольной формы размерами по дну $2,50 \times 1$ м и глубиной $-2,33$ м от $\mathrm{R}_{0}$ была ориентирована по линии запад-северо-запад - восток-юговосток. Стенки ямы расширялись ко дну. На глубине $-2,25$ м от $\mathrm{R}_{0}$ в центральной части ямы, среди фрагментов плах поперечного перекрытия, найдена часть тазовой кости крупного копытного животного (ло- шадь?), первоначально, вероятно, уложенная на перекрытие.

На дне ямы обнаружено парное захоронение, взрослого и ребенка, лежавших в вытянутом положении на спине, головой на запад-северо-запад.

Вдоль южной стенки ямы лежал костяк 1 (женщина 30-45 лет [10, р. 6]). Правая рука была вытянута вдоль тела, левая слегка отведена и кистью уложена вплотную к правой кисти костяка 2. Ноги прямые. У висков черепа костяка 1 найдены серебряные 
Синика В.С., Тельнов Н.П.

Курган 5 группы «Водовод» на левобережье Нижнего Днестра..

07.00.00 - исторические науки и археология

кольцевидные серьги (3). Под правым плечевым суставом лежало бронзовое зеркало (4) с утраченной деревянной рукоятью. На ее месте, возле отверстий для крепления, были найдены мелкие фрагменты дерева. Выше левого запястья зафиксирован браслет, состоявший из четырех роговых пронизей (9). Рядом найден бронзовый перстень с дисковидным щитком (5).

Вдоль северной стенки лежал костяк 2 (ребенок 6-7 лет [10, p. 7]). Его череп завалился на правый висок. Руки вытянуты вдоль тела, ноги прямые. Между правым запястьем и правым крылом таза была обнаружена подвеска из когтя птицы (10), а непосредственно под ней зафиксированы остатки стеклянного изделия (11). У левого колена костяка 2 найден фрагмент сланцевого абразива (12).

В северо-западном углу ямы, за черепом костяка 1, лежала лопатка крупного животного. Под ней найдены железные игла (6) и шило (7). Рядом лежали два лепных пряслица $(1,2)$. Под западной стенкой ямы зафиксировано скопление костей животных (КРС?), среди которых лежал железный нож с роговой рукоятью (8).

Поверх костяков и под ними отмечен толстый слой светло-серого органического тлена (от циновок?) (рис. $3 ; 4,5)$.

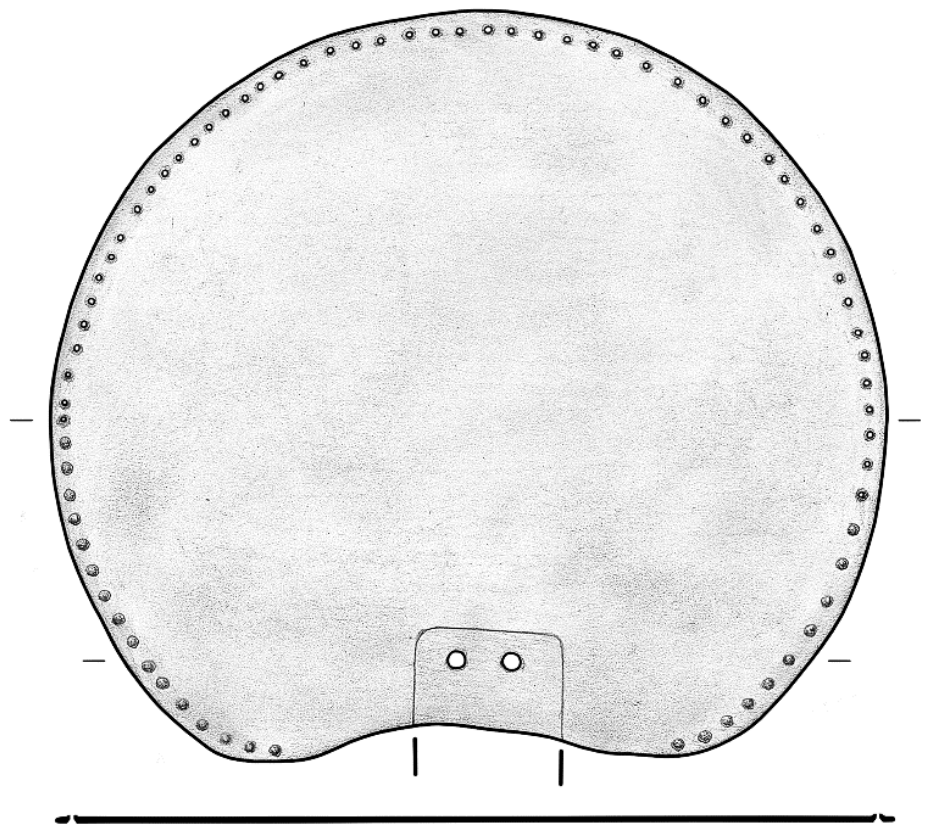

2
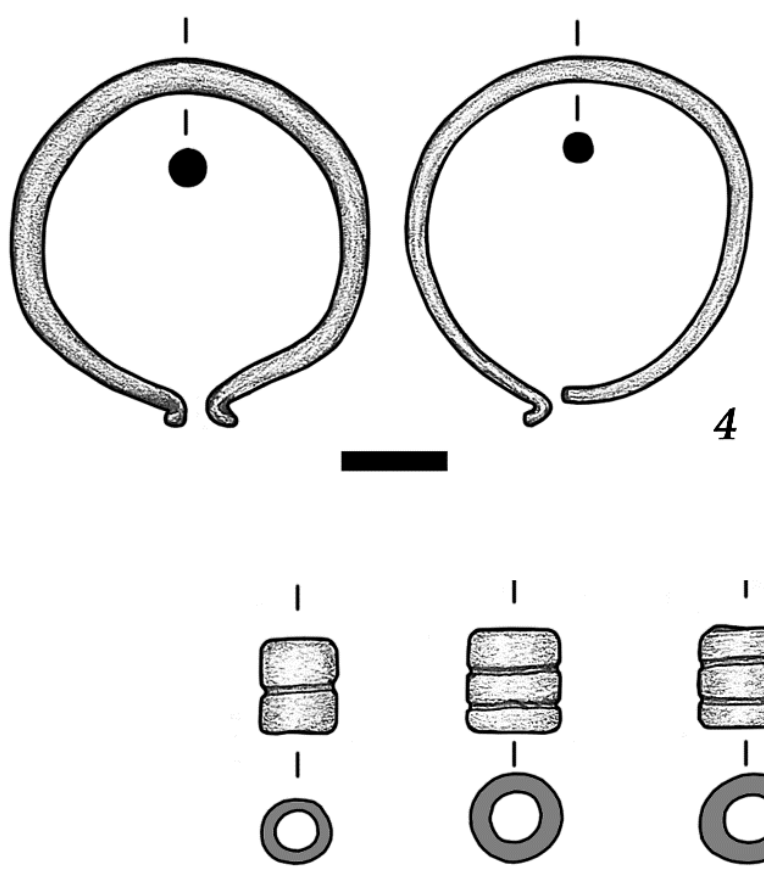
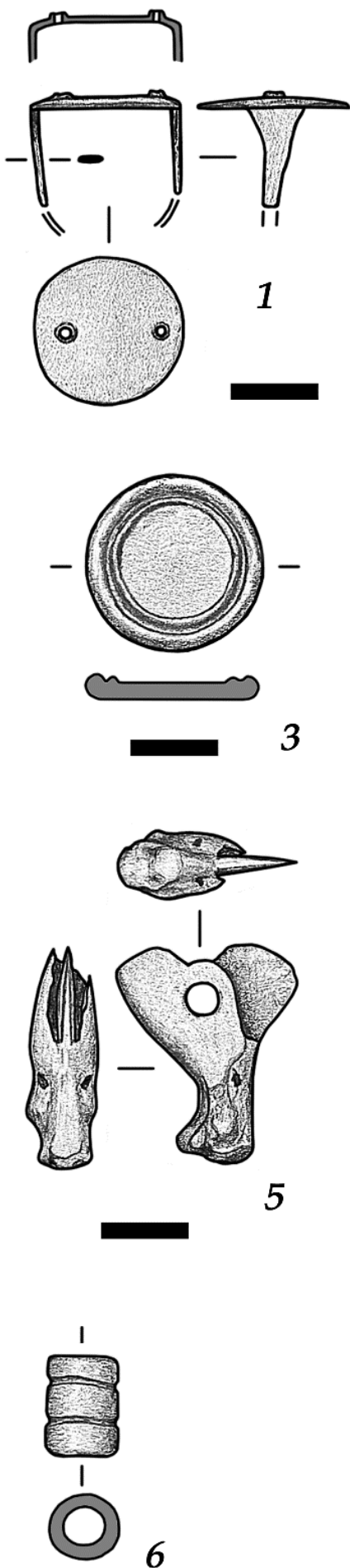

Рисунок 4 - Инвентарь погребения 5 кургана 5 группы «Водовод» 


\section{Описание находок}

1. Пряслице керамическое, биконическое. С одной стороны пряслице орнаментировано на торце прочерченным незамкнутым кольцом вокруг отверстия и прочерченным зигзагом по корпусу. Высота пряслица 25,8 мм, диаметр - 28,5 мм. Диаметр верхнего торца 14 мм, диаметр нижнего - 12 мм. Диаметр отверстия 4,7 мм (рис. 3: 7). Тесто с примесью мелкого шамота, мелкого песка. Цвет пятнами серый, темно-серый. Поверхности заглаженные.

2. Пряслице керамическое, биконическое. Высота пряслица 32 мм, диаметр - 30,6 мм. Диаметр верхнего торца 14 мм, диаметр нижнего - 15 мм. Диаметр отверстия 5,5 мм (рис. 3: 8). Тесто с примесью мелкого песка, мелкого шамота. Цвет красновато-бурый. Местами сохранился черный нагар. Поверхности шероховато-заглаженные.

3. Серьги серебряные (пара) кольцевидные, с несомкнутыми и отогнутыми наружу концами. На одной из серег один завиток обломан в древности. Обе серьги изготовлены из круглой в сечении проволоки с сужающимися концами. Размеры серег $33 \times 34,5$ мм и $34 \times 36,5$ мм (вместе с завитками), диаметр колец 33 мм и 34 мм. Диаметр проволоки 3 мм и 2,5 мм, диаметр проволоки на окончаниях 1,5 мм и 1,2 мм (рис. 4: 4).

4. Зеркало бронзовое дисковидное, с выемкой в месте соединения диска и несохранившейся деревянной ручки. Диск и ручка крепились двумя заклепками, расположенными вдоль торца. В месте крепления ручки сохранился четкий след от нее. По периметру диск украшен пуансоном; на половине окружности выпуклые «жемчужинки» превратились в отверстия вследствие изнашивания. Размеры диска $158 \times 141$ мм. Диаметр «жемчужин» - до 2 мм. Толщина пластины 1 мм. Ширина ручки 28 мм. Диаметр отверстий под заклепки 3,5 мм (рис. 4: 2).

5. Перстень бронзовый щитковый, с разомкнутой дужкой. В щитке изнутри напротив оснований дужки по краям пробито два отверстия, образующих с внешней стороны концентрические выступы. Диаметр щитка 18,3 мм; толщина - 1 мм. Длина сохранившейся части дужек 12 мм и 10 мм; ширина - от 6 мм до 2 мм и от 6,5 мм до 2,7 мм; толщина 1 1,5 мм. Диаметры отверстий около 0,8 мм; диаметры выступов до 2 мм, высота - до 0,5 мм (рис. 4: 1).

6. Игла железная. Изделие сильно коррозировано, в трех фрагментах. На одном конце расположена «лопатка» (ушко?). Стержень круглый в сечении. Длина иглы до 80 мм. Диаметр стержня 2,5-3 мм. Размеры «лопатки» $11 \times 6$ мм; толщина - до 3 мм (рис. 3: 10).

7. Шило железное. Изделие сильно коррозировано, в трех фрагментах. Стержень круглый в сечении. Рабочая часть, не входившая в деревянную рукоять, ромбическая в сечении. Длина шила около 83 мм. Длина рабочей части 13 мм. Диаметр стержня 2,53 мм. Размеры сечения у рукояти $2 \times 1,5$ мм (рис. 3: 9).

8. Нож железный с горбатой спинкой и остатками роговых накладок на рукоять. Роговые пластины крепились к черенку с двух сторон при помощи заклепок. Сохранившаяся длина ножа 122 мм. Сохранившаяся длина лезвия 89 мм, ширина лезвия до 17 мм, толщина - до 4 мм. Ширина рукояти около 16 мм. Толщина роговых пластин около 1,5 мм. Об- щая толщина рукояти около 6 мм. Длина заклепки без шляпок 6 мм; диаметр - 2 мм (рис. 3: 6).

9. Браслет с левого предплечья костяка 1 состоял из четырех роговых бусин. Бусины цилиндрические. Длина бусин от 9,3 мм до 11,8 мм, диаметр - от 7 до 9,6 мм. Диаметр отверстий от 4 мм до 6 мм. Только одна разделена одним поперечным желобком на две части, остальные три - трехчастные (рис. 4: 6).

10. Подвеска-амулет из дистальной фаланги (основание когтя) 1-го или 2-го пальца беркута (Aquila chrysaetos) [Определение директора Зоологического музея Приднестровского государственного университета (ПГУ) им. Т.Г. Шевченко им. Т.Г. Шевченко A.A. Тищенкова (30.08.2016 2).] в виде стилизованной морды лошади (?). Размеры подвески $25 \times 21,5$ мм, толщина - 8,5 мм. Диаметр отверстия 4 мм (рис. 4: 5).

11. Диск стеклянный. Изготовлен из синего стекла. Диск полностью рассыпался при расчистке; прорисован по полевым фотографиям и сохранившимся мелким фрагментам. Вдоль края по внешней стороне проходит сдвоенный бортик; внешнее кольцо более широкое и высокое, внутреннее - у́же и ниже. Диаметр изделия около 20 мм. Диаметр внутренней площадки около 13 мм. Толщина изделия не менее 3 мм (рис. 4: 3).

12. Абразив каменный, представляет собой обломок серого песчаника с пришлифованной широкой поверхностью. Размеры изделия 40,5 × $30 \times 19$ мм (рис. 3: 11).

Погребение 6 (скифское, впускное, кенотаф) обнаружено в I Восточной траншее, в 2 м на юг и в 3 м на восток от $\mathrm{R}_{0}$.

Яма прямоугольной формы размерами $1,48 \times$ $\times 0,63$ м и глубиной $-1,25$ м от $\mathrm{R}_{0}$ была ориентирована по линии север-северо-запад - юг-юго-восток. Стенки отвесные. Кости человека, инвентарь, тлен от подстилки не обнаружены (рис. 5: 1, 2).

Погребение 7 (скифское, основное) обнаружено под Центральной бровкой, в 2 м на север от $\mathrm{R}_{0}$. Coвершено в яме, к югу от которой на уровне древнего горизонта располагался односторонний материковый выкид подпрямоугольной формы длиной до 6 м, шириной до 3 м и толщиной до 0,1 м.

Яма подпрямоугольной формы размерами по дну $2,70 \times 1,45$ м и глубиной $-2,89$ м от $\mathrm{R}_{0}(2,49$ м от древнего горизонта) была ориентирована по линии запад-северо-запад - восток-юго-восток. Северная стенка нарушена грабительским ходом.

Погребение ограблено. В заполнении встречались фрагменты костей животных и человека возрастом 20 лет или более $[10$, p. 8]. В придонном заполнении ямы среди костей животных найдены фрагменты железных скреп (1) и фрагмент втока (2) (рис. 5: 3, 4).

\section{Описание находок}

1. Четыре скрепы железные от деревянного блюда. Скрепы подпрямоугольной формы, изготовлены из прута раскованного, в большинстве случаев, до подпрямоугольного сечения. Размеры скреп: 1) $40 \times 25$ мм (рис. 5: 5); 2) длина более 15 мм, высота 19 мм (рис. 5: 6); 3) длина около 43 мм (рис. 5: 7); 4) около $43 \times 25$ мм (рис. 5: 8).

2. Фрагмент втока дротика (?) железного. Длина фрагмента 25 мм. Диаметр втока 11 мм. Внутренний диаметр 6,5 мм. Во втулке сохранились остатки древка (рис. 5: 9). 
Погребение 8 (скифское, впускное) обнаружено под Восточной бровкой, в 2 м к северу от ее центра. Совершено в яме.

Яма прямоугольной формы размерами $1,85 \times$ $\times 0,45$ м и глубиной $-1,33$ м от $\mathrm{R}_{0}$ была ориентирована по линии запад-северо-запад - восток-юго-восток.
На дне ямы лежал костяк человека возрастом 20 лет или более $[10$, p. 8] в вытянутом положении на спине с разворотом на левый бок, головой на западсеверо-запад. Череп завалился на левый висок, руки вытянуты вдоль тела, ноги прямые.

Погребение безынвентарное (рис. 5: 10, 11).

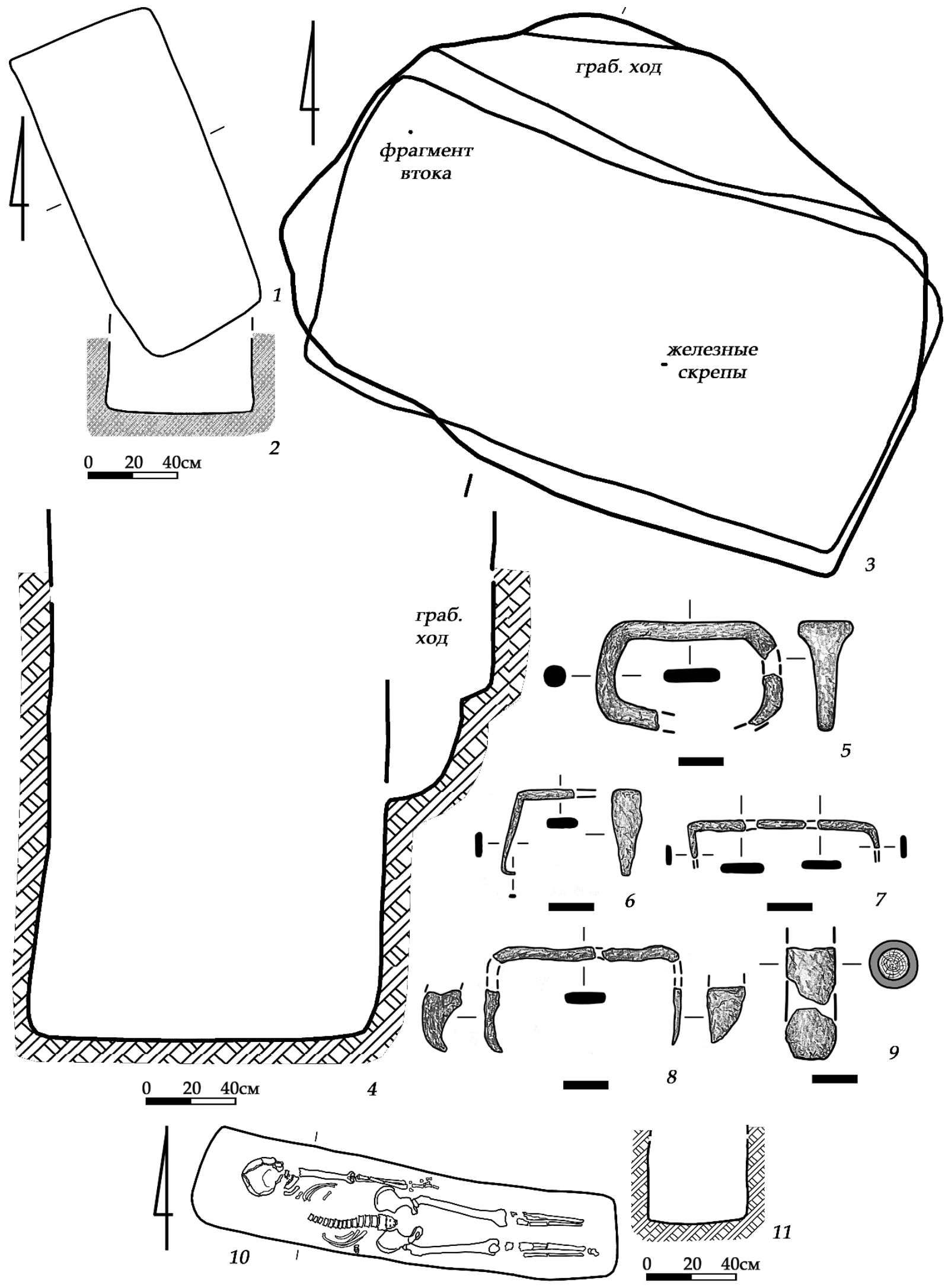

Рисунок 5 - План и профиль погребения $6(1,2)$; план и профиль захоронения $5(3,4)$ и находки из него (5-9); план и профиль погребения $8(10,11)$ 


\section{$* * * * *$}

Анализируя полученные материалы, необходимо констатировать, что курган 5 группы «Водовод» был сооружен для захоронения лиц с невысоким социальным статусом. Об этом свидетельствует материал из инвентарных неграбленых погребений 3,4 и 5, а также безынвентарное захоронение 8. Судя по трудозатратам на сооружение ограбленного в древности основного погребения 7, и оно принадлежало отнюдь не скифскому «аристократу». Возведен курган 5 был не ранее рубежа IV-III вв. до н.э., о чем свидетельствует амулет-подвеска в виде головы лошади, изготовленный из фаланги пальца беркута, из погребения 5 [7, с. 10]. Другие находки из кургана 5 значительно менее выразительны в хронологическом отношении.

Самый значительный интерес вызывает наличие под насыпью публикуемого кургана трех кенотафов - погребений 1,2 и 6.

Заметим, что скифы Северного Причерноморья практиковали сооружение символических погребений, однако везде (в Поднепровье, в Крыму, в Подонье) они малочисленны $[11$, с. $67,100,138]$. До недавнего времени и в Северо-Западном Причерноморье было известно всего три достоверных скифских кенотафа. В 1971 г. был исследован скифский курган 6 у с. Балабаны Чадыр-Лунгского района МССР (в настоящее время село входит в Тараклийский район Республики Молдова) в Дунай-Днестровском междуречье, в одном из основных погребений которого (6/1) были обнаружены только череп и кости ног лошади, а также амфора [12, с. 29, 37, рис. 11]. Сосуд принадлежит чертомлыкскому варианту (I-B) амфор типа Пепарет I, датированных третьей четвертью IV в. до н.э. [13, с. 99-100].

В 1975 г. на правобережье Днестровского лимана был раскопан скифский курган 20 у с. Семёновка Белгород-Днестровского района Одесской области. Основным комплексом в этом кургане являлся кенотаф. Он был устроен на уровне древнего горизонта и сопровождался не только депонированием предметов вооружения, конской упряжи, стеклянным кубком, а также сопутствующей тризной в виде амфорного и иного керамического боя, но и погребением зависимого лица, совершенным в катакомбе $[14 ; 15$, с. $97-$ 102 , 155-158, рис. 58-60]. Курган датируется последней третью/четвертью III в. до н.э. на основании клейменой родосской амфоры $[16$, с. 61,63 , рис. 7 : $1,2]$.

В 1980 г. в приморской части Дунай-Днестровского междуречья был изучен курган 48 у с. Кочковатое Татарбунарского района Одесской области. Под насыпью было выявлено погребение 4, стратиграфическая позиция которого осталась невыясненной: оно было либо совершено с двумя основными захоронениями (48/1 и 48/2) и сопровождало их, либо было впущено позже в насыпь. Кенотаф был устроен в яме, где были найдены «одна трубчатая кость животного и два астрагала овцы» [17, с. 48, 54, рис. 14: 9]. Комплекс датируется не ранее последней четверти IV в. до н.э. на основании железных наконечников стрел из одного из основных погребений (48/3) в кургане.

За последние 20 лет были открыты еще 11 кенотафов. В 1998 г. были исследованы курганы 1 и 2 группы Воловарската Могила к северу от с. Новокаменка Измаильского района Одесской области. Оба они представляли собой ограниченные кольцевыми рвами площадки безо всяких следов погребальных сооружений. На основании 18 гераклейских амфор изо рвов, в том числе одной клейменой, дата курганов определяется первой третью III в. до н.э. [18]. Спустя девять лет, в 2007 г., на левобережье Нижнего Днестра был изучен кенотаф в катакомбе 40/1 скифского могильника III-II вв. до н.э. у с. Глиное. Во входной яме катакомбы найдены железные удила и фрагменты лепной курильницы, а в погребальной камере - лепной светильник, однако эти находки не позволяют уточнить датировку данного комплекса [1, с. 270-271, 741-742, 966]. Наконец, в 2016 г. три детских кенотафа были обнаружены под насыпью кургана 5 группы «Водовод», публикуемого в настоящей работе, а в 2017 г. - пять детских кенотафов, из которых четыре были в курганах группы «Водовод» $(6 / 3,6 / 4,8 / 1$ и 8/4), и один - в кургане группы «Сад» (7/3). Только два из них оказались инвентарными: Глиное/Сад 7/3 - с лепной чашкой, Глиное/Водовод 8/4 - с фрагментом железного трехлопастного наконечника стрелы. Все восемь детских кенотафов в курганах групп «Водовод» и «Сад» были совершены в ямах. Их суммарная датировка охватывает последнюю четверть IV - первую треть III в. до н.э. (раскопки 2017 г.; материаль в печати).

Таким образом, в настоящее время мы располагаем данными о 14 скифских кенотафах в Северо-Западном Причерноморье.

Самый ранний из них датируется третьей четвертью IV в. до н.э. (Балабаны 6/1), а самый поздний либо последней третью III в. до н.э. (курган 20 у с. Семёновка), либо II в. до н.э. (Глиное 40/1). При этом 13 кенотафов (за исключением погребения Балабаны 6/1) были совершены в последней четверти IV-II в. до н.э. Скорее всего, увеличение числа кенотафов в Северо-Западном Причерноморье именно в этот период связано с седентаризацией скифского населения региона. Отмечено, что в Нижнем Поднепровье процесс оседания степных скифов начался не позднее середины IV в. до н.э. [19, с. 94-184, 321]. В полной мере это относится и к другим регионам Cеверного Причерноморья, в частности к Нижнему Поднестровью. Здесь известны такие памятники, как Надлиманское городище [20], поселение и грунтовый могильник у с. Николаевка [21], могильник у с. Глиное Слободзейского района [1], а также ряд других поселений, функционировавших в III-II вв. до н.э.: Паланка на правобережье Днестра [22]; Токмазея [23], Парканы-II [24], Слободзея-VI [25], Чобручи [26; 27] и Красное [28] - на левобережье. О значительной оседлости скифского населения Нижнего Поднестровья в III-II вв. до н.э. свидетельствует анализ инокультурных влияний на погребальный обряд и вещевой комплекс [29; 30, с. 272; 31, с. 77-78], традиция устройства погребальных камер катакомб (реже дромосов) в виде наземных жилищ [32, с. 35], а также комплекс вооружения [33, с. 189], лепные миски [34, с. 311-312], и светильники [35, с. 203] из скифского могильника у с. Глиное. О возрастании количества оседлого скифского населения в Нижнем Поднестровье с последней четверти IV в. до н.э. свидетельствуют и кенотафы в курганных группах «Водовод» и «Сад», расположенные поблизости от упомянутого выше могильника III-II вв. до н.э. у с. Глиное на левобережье Нижнего Днестра. Представить, что все восемь упомянутых выше детских кенотафов были устроены скифам-кочевникам, весьма проблематично. Значительное число детских захоронений, в 
том числе и детских кенотафов (более $50 \%$ от общего числа исследованных к 2017 г. захоронений), позволяет считать, что все они были совершены оседлыми скифами. В полной мере это относится к кургану 20 у с. Семёновка на правобережье Днестровского лимана и к погребению 40/1 могильника у с. Глиное на левобережье Нижнего Днестра.

Значительно сложнее связать сооружение курганов-кенотафов 1 и 2 группы Воловарската Могила на левобережье Нижнего Дуная, а также погребений 6/1 у с. Балабаны и 48/4 у с. Кочковатое в ДунайДнестровском междуречье, с процессом оседания скифов на землю. Слои IV-II вв. до н.э. на городище Новосельское-II, расположенном у с. Орловка Ренийского района Одесской области, на основании анализа лепной керамики связываются с гетами как «доминировавшей группой, обитавшей на поселении» [36, с. 333]. В то же время в 0,65 км к западу от с. Новокаменка, между реками Большой и Малый Катлабух, был исследован многослойный памятник Кале (Новокаменка III). Наряду с прочими, на нём выявлены материалы скифского «стойбища» - фрагменты амфор и лепной посуды, а также монета Тиры IV в. до н.э. [37, с. 35 , рис. 1$]$.

В связи с этим проведем более детальный анализ скифских кенотафов, чтобы выяснить, с какой целью их сооружали. В настоящее время очевидно, что невозможность предания тела умершего земле является не более чем самым общим объяснением причины устройства кенотафов. Также актуально понять, были ли все перечисленные комплексы действительно кенотафами.

Предположения о том, что некоторые погребения кенотафами не были, не беспочвенны. В частности, комплекс Балабаны 6/1 был устроен одновременно, что зафиксировано стратиграфическими данными, с погребением Балабаны 6/2. Последнее представляло собой захоронение женщины (парные серьги, зеркало, фрагменты веретена, два пряслица) с предметами вооружения - двумя копьями и 150 стрелами в колчане [12, с. 28-37]. Возможно, «захоронение» 6/1 с черепом и костями ног лошади и с амфорой представляло собой яму, куда положили чучело лошади, с помощью которой воительница должна была вернуться в мир живых [1, с. 730; 38, с. 121]. В таком случае, комплекс 6/1 не был ямой для символического захоронения человека, а специальным вспомогательным сооружением, имевшим особое культовое значение. Аналогичный комплекс (захоронение взнузданной лошади и хозяина в двух близко расположенных ямах) был выявлен в кургане 9 у с. Никольское на левобережье Нижнего Днестра [39, c. $96,98,100$, рис. 47,48$]$. Насыпь была возведена в первой половине V в. до н.э. [40, с. 33-34, рис. 7: 7].

Комплекс 48/4 у с. Кочковатое, по всей видимости, был также устроен одновременно с основными захоронениями 48/1 и 48/2 и находился на одной оси с погребениями 48/3 (северо-восток) и 48/1 (центр), занимая юго-западную позицию на площадке, ограниченной кольцевым рвом [17, с. 48,54 , рис. 14: 9]. Находки костей животных при отсутствии костей человека допускают возможность интерпретации данного комплекса как ритуальной ямы, где совершались тризны во время сооружения и совершения погребений. Такие ямы известны в других курганах Северо-Западного Причерноморья [1, с. 930, табл. 26; 41 , с. $22 ; 42$, с. 125-126].
Возможно, что курганы 1 и 2 группы Воловарската Могила также не являлись кенотафами. Они могли быть не погребальными комплексами, а поминальными площадками для ритуальных возлияний. На это может указывать солидный набор амфорной тары из курганов, общий объем которой составляет ок. 100 л, а также соседство с крупнейшим в группе курганом - Воловарската Могила (диаметром 85 м). Если последняя была сооружена скифами, причем в то же время, что и курганы 1 и 2, такая версия имеет право на существования [18].

В то же время необходимо подчеркнуть, что все высказанные соображения не позволяют безоговорочно исключать погребения 6/1 у с. Балабаны, 48/4 у с. Кочковатое, а также курганы 1 и 2 группы Воловарската Могила из списка скифских кенотафов Северо-Западного Причерноморья, поскольку абсолютной уверенности в том, что они не предназначались для символических захоронений людей, нет.

Однако такая уверенность существует, когда речь идет о кургане 20 у с. Семёновка, где основное символическое погребение сопровождалось не только депонированием предметов вооружения, конского снаряжения и тризной в виде керамического боя, но и захоронением зависимого лица в катакомбе $[14 ; 15$, c. 97-102, 155-158, рис. 58-60). Кенотаф в катакомбе 40/1 могильника у с. Глиное также был инвентарным [1, с. 270-271, 741-742, 966], и сомневаться в том, что он предназначался для погребения человека, не приходится. Это относится и к инвентарным кенотафам Глиное/Сад 7/3 и Глиное/Водовод 8/4, несмотря на отсутствие в них следов подстилок и человеческих костей. Безынвентарные кенотафы группы Водовод у с. Глиное $(5 / 1,5 / 1,5 / 6,6 / 3,6 / 4,8 / 1)$, очевидно, также предназначались для символических захоронений детей. Об этом, с одной стороны, свидетельствует отсутствие каких-либо данных о возможности их иного использования. С другой стороны, указанные кенотафы зафиксированы в курганах, где были найдены детские захоронения, содержавшие останки погребенных и инвентарь (Глиное/Сад 7/1, $7 / 2,7 / 4$; Глиное/Водовод 5/3, 6/1, 6/2, 8/2). С учетом одинаковой степени сохранности органических материалов под насыпями, содержащими как детские погребения с костяками, так и детские кенотафы, нет оснований считать последние захоронениями младенцев, кости которых истлели полностью.

Суммируя изложенное, можно заключить, что использование некоторых подкурганных сооружений скифами Северо-Западного Причерноморья в качестве кенотафов может быть оспорено. В то же время существование настоящих кенотафов (подкурганных комплексов, с погребальным сооружением или без него), предназначавшихся для символических захоронений людей, тела которых по каким-либо причинам не могли быть преданы земле, сомнений не вызывает.

\section{Список литературы:}

1. Тельнов Н.П., Четвериков И.А., Синика В.С. Скифский могильник III-II вв. до н.э. у с. Глиное (Археологические памятники Приднестровья III). Тирасполь: Stratum plus, 2016. 1096 с.

2. Синика В.С., Тельнов Н.П. Скифский курган 116 первой половины III в. до н.э. у с. Глиное // Древности. Исследования и проблемы (отв. ред. Синика В.С., Рабинович Р.А.). Кишинев - Тирасполь: Stratum plus, 2018. C. 223-266. 
Синика В.С., Тельнов Н.П.

3. Синика В.С., Тельнов Н.П. Скифский курган № 1 группы «Водовод» на левобережье Нижнего Днестра // Емінак. 2016. № 4 (16). С. 45-53.

4. Синика В.С., Тельнов Н.П. Скифское захоронение с тамгой рубежа IV-III вв. до н.э. с левобережья Нижнего Днестра // Новое прошлое. 2016. № 4. C. $258-272$.

5. Синика В.С., Тельнов Н.П. Скифское погребение с литиком-скарабеоидом с левобережья Нижнего Днестра // Стародавнє Причорномор'я. Вип. XI (голов. ред. І.В. Нємченко). Одеса: Одеський національний університет імені I.I. Мечникова, 2016. C. $488-499$.

6. Синика В.С., Тельнов Н.П. Скифские курганы 2 и 3 группы «Сад» в Нижнем Поднестровье // Новое прошлое, 2017. № 4. С. 286-306.

7. Синика В.С., Тельнов Н.П. Скифское погребение с уникальным амулетом с левобережья Нижнего Днестра // Научные ведомости БелГУ. Сер. История. Политология, 2017. № 8 (257), Вып. 42. С. 5-12.

8. Синика В.С., Тельнов Н.П. Скифское погребение с фракийской фибулой на Нижнем Днестре // Stratum plus, 2017. № 3. C. 131-152.

9. Панковский В.Б., Синика В.С. Роговой гребень из скифского погребения у с. Глиное // Stratum plus, 2017. № 3. C. 343-359.

10. Łukasik S. Anthropological analysis of human skeletal remains from Glinoe Vodovod site, Moldova: barrows 2-6 and 8. Poznań, 8 January 2018. Report submitted to the Taras Shevchenko University in Tiraspol. $11 \mathrm{p}$.

11. Ольховский В.С. Погребально-поминальная обрядность населения степной Скифии (VII-III вв. до н.э.). М.: Наука, 1991. 256 с.

12. Чеботаренко Г.Ф., Яровой Е.В., Тельнов Н.П. Курганы Буджакской степи. Кишинев: Штиинца, 1989. $212 \mathrm{c}$.

13. Монахов С.Ю. Греческие амфоры в Причерноморье: типология амфор ведущих центров-экспортеров товаров в керамической таре. М.: Киммерида; Саратов: СГУ, 2003. $352 \mathrm{c.}$

14. Разумов С.Н., Синика В.С. «Новый» скифский комплекс III в. до н.э. на правобережье Нижнего Днестра // Вестник ВолГУ. Серия 4. История. Регионоведение. Международные отношения. 2017. Т. 22 (3). C. 6-19.

15. Субботин Л.В., Разумов С.Н., Синика В.С. Семёновские курганы (Археологические памятники Приднестровья IV). Тирасполь: Stratum plus, 2017. $180 \mathrm{c}$.

16. Зайцев Ю.П. Античная керамика в ритуальных (вотивных) кладах Северного Причерноморья // Древности Северного Причерноморья III-II вв. до н.э.: мат-лы Междунар. науч. конф., г. Тирасполь, 16-19 октября 2012 г. (отв. ред. Тельнов Н.П.). Тирасполь: ПГУ, 2012. С. 55-66.

17. Ванчугов В.П., Субботин Л.В., Дзиговский А.Н. Курганы приморской части Днестро-Дунайского междуречья. К.: Наукова думка, 1992. 92 с.

18. Фокеев М.М., Синика В.С., Руссев Н.Д. Скифские курганы-кенотафы группы Воловарската Могила на левобережье Нижнего Дуная // Stratum plus. 2018. № 3.

19. Гаврилюк Н.А. Экономика Степной Скифии VI-III вв. до н.э. К.: Издатель Олег Филюк, 2013. $712 \mathrm{c}$.
20. Дзис-Райко Г.А., Охотников С.Б., Редина Е.Ф. Городище Надлиманское IV-III вв. до н.э. в Нижнем Поднестровье: материалы по археологии Северного Причерноморья (монографическая серия). Одесса: СМИЛ, 2012. 264 c.

21. Мелюкова А.И. Поселение и могильник скифского времени у села Николаевка. М.: Наука, 1975. $260 \mathrm{c}$.

22. Ткачук М.Е., Топал Д.А., Зверев Е.Ю. Археологические разведки у с. Паланка: новое античное поселение на Нижнем Днестре // Культурные взаимодействия. Динамика и смыслы (отв. ред. Церна С., Говедарица Б.). Кишинев: Stratum plus, 2016. С. 367377.

23. Синика В.С. Латенская фибула из Токмазеи // Вестник ВГУ. Сер. История. Политология. Социология. 2017. № 2. С. 111-115.

24. Синика В.С. Новый памятник III-II вв. до н.э. на левобережье Нижнего Днестра // Вестник НВГУ, 2017. № 2. C. 122-129.

25. Синика В.С., Иващенко М.В. 2017. Комплекс находок III в. до н.э. из поселения у Слободзеи // Известия Самарского научного центра РАН. 2017. T. 19, № 3. C. 223-228.

26. Иващенко М.В. Амфорные клейма из поселения Чобручи на левобережье Нижнего Днестра // Древности Северного Причерноморья III-II вв. до н.э.: мат-лы Междунар. науч. конф., г. Тирасполь, 1619 октября 2012 г. (отв. ред. Тельнов Н.П.). Тирасполь: ПГУ, 2012. С. 81-86.

27. Фидельский С.А., Иващенко М.В., Синика В.С. Амфорные клейма причерноморских центров с поселения Чобручи на левобережье Нижнего Днестра. Stratum plus, 2017. № 6. C. 329-346.

28. Синика В.С., Тащи Е.Ф., Тельнов Н.П., Четвериков И.А. Поселение Красное на левобережье Нижнего Днестра. Stratum plus, 2012. № 3. С. 187-215.

29. Синика В.С. О латенском влиянии на материальную культуру скифского могильника III-II вв. до н.э. у с. Глиное на левобережье Нижнего Днестра // Древность: историческое знание и специфика источника: мат-лы междунар. науч. конф., посв. Памяти Э.А. Грантовского и Д.С. Раевского (Москва, 12 14 декабря 2011 г.). Вып. V (отв. ред. Балахванцев А.С., Колганова Г.Ю.). М.: ИВ РАН, 2011. C. 184-187.

30. Синика В.С. О греческом влиянии на погребальный обряд и материальную культуру скифского могильника III-II вв. до н.э. у с. Глиное на левобережье Нижнего Днестра // Человек в истории и культуре. Вып. 2. Мемориальный сб. мат-лов и исследований в память лауреата Гос. премии Украины, академика РАЕН, профессора Владимира Никифоровича Станко (отв. ред. Пригарин А.А.). Одесса: Смил, 2012. C. 264-272.

31. Тельнов Н.П., Синика В.С. Фракийские влияния на материальную культуру и погребальный обряд скифов III-II вв. до н.э. на левобережье Нижнего Днестра. Revista arheologică. S. n., 2012. Vol. VIII. Nr. 1-2, P. 69-83.

32. Синика В.С., Тельнов Н.П. Скифские жилища IV-II вв. до н.э. в Северном Причерноморье // Apхеологія і давня історія України. Вип. 2 (13) (гол. ред. Скорий С.А.). Київ: ІА НАНУ, 2014. С. 18-36. 
33. Синика В.С., Тельнов Н.П. Комплекс вооружения и предметов воинского снаряжения из скифского могильника конца IV-II вв. до н.э. у с. Глиное в Нижнем Поднестровье // Война и военное дело в скифо-сарматском мире (отв. ред. Лукьяшко С.И.). Ростов-на-Дону: ЮНЦ РАН, 2015. С. 180-190.

34. Тельнов Н.П., Синика В.С. Миски из скифских погребальных памятников конца IV-II в. до н.э. на левобережье Нижнего Днестра // Tyragetia. S. n. 2014. Vol. VIII (XXIII), nr. 1. C. 287-316.

35. Синика В.С., Тельнов Н.П. Светильники в погребальном обряде скифов Северного Причерноморья // Tyragetia. S. n. 2015. Vol. IX (XXIV), nr. 1, P. 183-208.

36. Бруяко И.В., Ванчугов В.П., Савельев О.К. Слои эллинистического времени на городище Новосельское-II // Материалы по археологии Северного Причерноморья, 2012. Вып. 12. С. 294-335.

37. Гудкова А.А., Рандсборг К., Руссев Н.Д., Фокеев М.М. Археологические исследования Буджакской экспедиции в микрорайоне села Суворово // Охрана и исследование памятников археологии в Одесской области. Вып. I (отв. ред. Штербуль Н.А.). Одесса: Астро-Принт, 1999. С. 34-37.
38. Синика В.С. К вопросу о семантике конских погребений на скифском могильнике III-II вв. до н.э. у с. Глиное на левобережье Нижнего Днестра // Археологія і давня історія України. Вип. 5 (відп. ред. Отрощенко В.В.). Археологія: від джерел до реконструкцій. Київ. ІА НАНУ, 2011. С. 119-124.

39. Агульников С., Сава Е. Исследования курганов на левобережье Днестра. Кишинев: CEP USM, 2004. 243 c.

40. Канторович А.Р. Изображение обособленных конечностей хищников в искусстве скифского звериного стиля Восточной Европы: типология, хронология, анализ истоков и эволюции // Stratum plus, 2012. № 3. С. 17-71.

41. Синика В.С. Погребальные памятники скифской культуры VII - начала III в. до н.э. на территории Днестро-Прутско-Дунайских степей: автореф. дис. ... канд. ист. наук. М., 2007. 28 с.

42. Синика В.С. Погребальные памятники скифской культуры VII-начала III в. до н.э. на территории Днестро-Прутско-Дунайских степей: дис. ... канд. ист. наук. М., 2007. 238 с.

\title{
BARROW 5 OF THE «SLUICEWAY» GROUP ON THE LEFT BANK OF THE LOWER DNIESTER AND SCYTHIAN CENOTAPHS OF THE NORTH-WEST BLACK SEA REGION
}

(C) 2018

Sinika Vitalij Stepanovich, candidate of historical sciences, associate professor, leading researcher of Archaeology Scientific Laboratory; senior researcher of Historiography and Field Methods in Archaeology Laboratory Pridnestrovian State University (Tiraspol, Republic of Moldova);

Nizhnevartovsk State University (Nizhnevartovsk, Khanty-Mansi Autonomous Okrug - Yugra, Russian Federation)

Telnov Nikolai Petrovich, candidate of historical sciences, associate professor, head of Antique and Medieval Archeology Department

Institute of Cultural Heritage of Academy of Sciences of Moldova (Kishinev, Republic of Moldova)

Abstract. The paper publishes and analyzes the Scythian barrow 5 of the «Sluiceway» group of barrows located near Glinoe village, Slobodzeya District, on the left bank of the Lower Dniester. The mound was erected at the turn of the $4^{\text {th }}-3^{\text {rd }}$ centuries BC and contained eight Scythian funeral structures, three of which were cenotaphs. Only 14 such symbolic graves are known in the North-West Black Sea region. In addition to the three graves published in the present work, there is Balabany 6/1, Semyonovka 20, Kochkovatoe 48/4, Volovarskata Mogila 1 and 2, Glinoe 40/1, Glinoe/Sluiceway $6 / 3,6 / 4,8 / 1$ and $8 / 4$, Glinoe/Garden $7 / 3$. They were made in the second half of the $4^{\text {th }}-2^{\text {nd }}$ centuries BC. A significant number of children's cenotaphs (8), allows us to assume that they were all made by settled Scythians. The use of some of the complexes (4 cases) as cenotaphs can be impugned. At the same time, there are no doubts about the existence of real cenotaphs (under-barrow complexes, with or without funeral structures) intended for symbolic internment of people (10 cases), whose bodies could not be betrayed to earth for any reasons.

Keywords: Scythians; border of $4^{\text {th }}-3^{\text {rd }}$ centuries BC; left bank of Lower Dniester; steppe; funeral rite; barrow; grave; pit; catacomb; cenotaph; material culture; handmade pot; necklace from beads; amulets-pendants; spindle whorls; earrings; mirror; finger ring; needle; awl; abrasive; settled way of life; left bank of Lower Danube Region; Danube-Dniester interfluve.

УДК 903’3

Статья поступила в редакцию 22.10.2017

\section{ГЛИНЯНАЯ ПЛАСТИКА ОБЬ-ИРТЫШСКОГО МЕЖДУРЕЧЬЯ ПЕРВОЙ ПОЛОВИНЫ І ТЫСЯЧЕЛЕТИЯ НАШЕЙ ЭРЫ}

(C) 2018

\author{
Ломов Павел Константинович, старший лаборант отдела охранно-спасательной археологии \\ Новиков Андрей Владиленович, кандидат исторических наук, \\ старший научный сотрудник отдела археологии палеометалла \\ Институт археологии и этнографии СО РАН (г. Новосибирск, Российская Федерация)
}

\footnotetext{
Аннотаџия. Раннесредневековая глиняная пластика Обь-Иртышского междуречья, являясь важным и информативным источником для разработки ряда проблем археологии Западной Сибири, остается практически неисследованной. За более чем вековую историю археологического изучения региона накоплена немногочисленная, но довольно показательная коллекция глиняных пластических изображений, относимых исследо-
} 